\title{
SPECIES COMPOSITION, DISTRIBUTION, AND POTENTIAL YIELD OF DEEP SEA SHRIMP RESOURCES IN THE WESTERN SUMATERA OF THE INDIAN OCEAN EEZ OF INDONESIAN WATERS
}

\author{
Ali Suman"), Wudianto"), and Gatut Bintoro")
}

\begin{abstract}
Study on the catch composition, distribution and potential yield of deep sea shrimp in the western off Sumatera waters was conducted on June to July 2005 using RV Baruna Jaya IV with trawl net. This study was basically carried out by employing swept area method. The results show that the catch of shrimps were consisted of five families with 33 species and the catch of shrimp was dominated by Heterocarpus sp. around of $31 \%$ and stout red shrimp (Aristeus virilis) around of $24 \%$. In general, distribution of deep sea shrimp resources found on the depth range of 200 to $1,000 \mathrm{~m}$ and species Aristeus virilis has a wide distribution in this area. Distribution of deep sea shrimp resources was higher on the depth of 750 to $1,000 \mathrm{~m}$ and lower on the depth of 200 to $500 \mathrm{~m}$ and distributed mostly at S-1 area (off Enggano Island) and rarely at S-5 area (off Aceh). Stock density of deep sea shrimp in this area fluctuated from 1,7 to $88,1 \mathrm{~kg} \mathrm{~km}^{-2}$ with the mean of stock density was $22.0 \mathrm{~kg} \mathrm{~km}^{-2}$. The biomass of deep sea shrimp in the west off Sumatera waters was estimated 217 ton with potential yield around of
109 ton/year.
\end{abstract}

KEYWORDS:
Indian Ocean
Indian composition, distribution, potential yield, deep sea shrimp resources,

\section{INTRODUCTION}

Shrimp production in Indonesia was mostly resulted from small scale fisheries. Generally fishing ground of the shrimp was only located around on shallow waters less than $100 \mathrm{~m}$ depth which occupied about $50 \%$ of Indonesian waters (Naamin, 1987). The production of shrimp in this area has already been in stagnant level due to the increase of fishing effort. In the recent estimation of shrimp production in the waters has been reached $268 \%$ of its (maximum sustainable yield) level (RCCF, 2003). This fact informed that the shrimp resource in this water was seriously in danger. Therefore, exploitation of shrimp resource in the waters should strongly be reduced in order to save the resources.

Study to find extended shrimp fishing ground is urgently needed to recover national shrimp production due to the limitation of shrimp exploitation in Indonesian waters below $100 \mathrm{~m}$ depth. Deep sea shrimp is one of new shrimp resources in Indonesian waters. This resource has not properly utilized yet due to huge area of Indonesian deep sea waters. Three type of research activities related to biology aspect, fishing ground, and stock abundance of the deep sea shrimp have been carried out in the Indian Ocean Indonesia especially in south of Java and western

\footnotetext{
") Research Institute for Marine Fisheries, Muara Baru-Jakarta

") Politeknik Pertanian Perikanan Pangkep, Sulawesi Selatan
}

of Sumatera. Naamin (1984) stated that information of new shrimp resource is very important to develop utilization of the shrimp stock. Furthermore Sumiono \& Iskandar (1993) reported that some species of deep sea shrimps were found during Karubar expedition, conducted around of Kai, Aru, and Tanimbar waters. Another research in deep sea waters using Korean Research Vessels, Oh Dae San informed that Solenocera prominentis was caught around south of Java Island in the depth of $200 \mathrm{~m}$ (Anonimous, 1972). George (1967) also reported that some penaeid prawn that was found from the offshore of Bali waters, Flores Sea, Makassar Strait, Banda Sea, and Arafuru Sea.

This study discusses species composition, distribution, and stock density of the deep sea shrimp in the Indian Ocean especially in the waters western of Sumatera. The result of this study can hopefully be used as a fundamental information for further research and developing the deep sea shrimp utilization.

\section{MATERIALS AND METHODS}

The study was conducted in the Indian Ocean western of Sumatera as shown in Figure 1 and implemented in the frame work of the Deep Sea Fisheries Resources Joint Exploration Project 


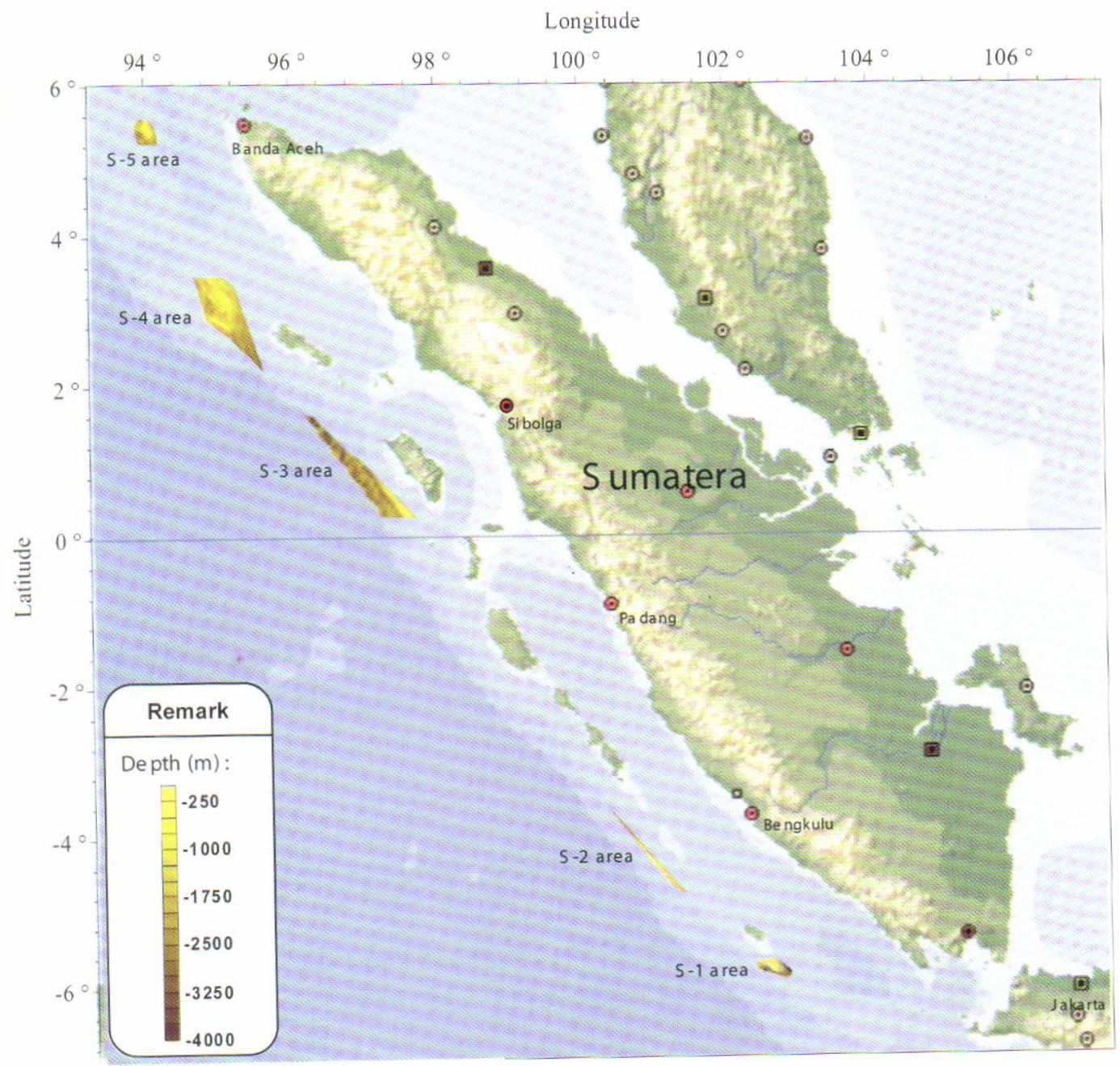

Figure 1.

Map of Indian Ocean west off Sumatera showing location of survey area.

between Overseas Fishery Cooperation Foundation Japan and Agency of Marine and Fisheries Research; Indonesia. The period of this study was from June to July 2005.

The survey area in the waters west of Sumatera Island was divided into five sub areas along longitudinal line, for the sake of convenience for allocating trawl stations (Figure 1). Nevertheless, one of those areas (S-3 area, in the western part of Nias Island) was cancelled because of the absence of trawl suitable depth zone. Each sub area was stratified into three depth zones by the depth contours of 500 and $750 \mathrm{~m}$ according to the result of the survey in 2004 (Anonimous, 2005). The number of trawl stations based on area surveyed and depth stratified as illustrated in Table 1.

The research was conducted using Baruna Jaya IV $(1,219 \mathrm{GT})$ by operating trawl net with head rope of $31.6 \mathrm{~m}$ in length (Anonimous, 2005). Species identification for deepsea shrimp was based on
King (1986); Holthuis (1991); Carpenter \& Niem (1998).

For estimation of stock density was applied formula that introduced by Shindo (1973); Saeger et al. (1976); Sparre and Venema (1992) as follow:

$$
\begin{aligned}
& a=V \cdot t \cdot h \cdot X^{2} \\
& Q=C w / a\left(\mathrm{~kg} \mathrm{~km}^{-2}\right) \\
& B=\operatorname{average~} Q / 0.5\left(\mathrm{~kg} \mathrm{~km}^{-2}\right) \\
& P y=0.5 \mathrm{~B}
\end{aligned}
$$

where:

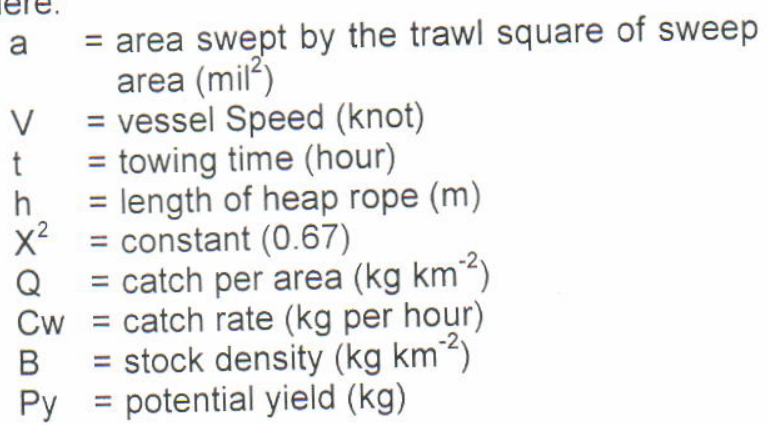


Table 1. Survey areas and allocated trawl stations for fish stock assessment in west off Sumatera waters

\begin{tabular}{|c|c|c|c|c|c|c|c|c|}
\hline \multirow[b]{2}{*}{ Area code } & \multicolumn{4}{|c|}{ Area $\left(\mathrm{km}^{2}\right)$} & \multicolumn{4}{|c|}{ Number of trawl stations } \\
\hline & $200-500 m$ & $500-750 m$ & $750-1,000 m$ & Sub total & $\begin{array}{c}200- \\
500 \mathrm{~m}\end{array}$ & $\begin{array}{c}500- \\
750 \mathrm{~m} \\
\end{array}$ & $\begin{array}{c}750- \\
1,000 \mathrm{~m}\end{array}$ & Total \\
\hline Sumatera & & & & & & & & \\
\hline S-1 area & 308.24 & 309.76 & 414.96 & $1,032.96$ & 3 & 3 & 4 & 10 \\
\hline S-2 area & 0.00 & 18.37 & 98.31 & 116.68 & 0 & 2 & 2 & 4 \\
\hline $\begin{array}{l}\text { S-4 area } \\
\text { S-5 area }\end{array}$ & 218.70 & $1,871.97$ & $2,429.85$ & $4,520.51$ & 1 & 12 & 12 & 25 \\
\hline S-5 area & 341.72 & 510.00 & 602.46 & $1,454.18$ & 3 & 4 & 4 & 11 \\
\hline $\begin{array}{c}\text { Sumatera } \\
\text { total }\end{array}$ & 868.66 & $2,710.09$ & $3,545.57$ & $7,124.32$ & 7 & 21 & 22 & 50 \\
\hline
\end{tabular}

\section{RESULTS AND DISCUSSION}

\section{Species Composition of Deep Sea Shrimp}

Total catch of deepsea shrimp during survey in the western of Sumatera waters recorded $29.88 \mathrm{~kg}$ which consisted of 33 species, was dominated by
Heterocarpus sp. (30.75\%) and Aristeus virilis $(23,79 \%)$ as presented in Table 2 . That also shows that some commercially species were found in this area as Aristeus virilis, Plesiopenaeus edwardsianus, Heterocarpus spp., and Plesionika spp., as shown in Appendix 1. Those species have been exploited by commercial fishing industries in

Table 2. Catch composition of deep sea shrimp in Indian Ocean west off Sumatera

\begin{tabular}{lc}
\hline \multicolumn{1}{c}{ Species } & Percentage (\%) \\
\hline Aristaeomorpha foliacea & 0.93 \\
Aristeus virilis & 23.79 \\
Plesiopenaeus edwardsianus & 10.68 \\
Nephrops stewaili & 0.28 \\
Puerulus angulatus & 0.27 \\
Acanthephyra armata & 8.18 \\
Acanthephyra sp. & 0.52 \\
Eugonatonotus sp. & 0.05 \\
Heterocarpus dorsalis & 0.04 \\
Heterocarpus ensifer & 0.27 \\
Heterocarpus laevigatus & 3.65 \\
Heterocarpus parvispina & 0.42 \\
Heterocarpus sp. & 30.75 \\
Heterocarpus sp.1 & 0.38 \\
Heterocarpus sp. 2 & 0.64 \\
Heterocarpus sp. 3 & 1.42 \\
Parapandalus seratifrons & 0.54 \\
Periclimenes sp. & 0.06 \\
Plesionika ensis & 3.66 \\
Plesionika longirostris & 0.61 \\
Plesionika martia & 1.78 \\
Plesionika sp. & 0.1 \\
Stylodactylus stebbingi & 0.2 \\
Stylodactylus sp. & 0.03 \\
Parapenaeopsis sp. & 0.03 \\
Penaeopsis eduardoi & 0.51 \\
Acetes sp. & 3.94 \\
Acetes sp. 1 & 1.19 \\
Sergestes sp. & 1.07 \\
Sergestes sp. 1 & 0.96 \\
Solenocera alfonso & 1.29 \\
Solenocera sp. & 1.49 \\
Solenocera sp. 1 & 0.26 \\
\hline
\end{tabular}


West Australia waters since 20 years ago (Wallner \& Phillips, 1988).

A research conducted in Kai, Aru, and Tanimbar Islands waters also found the same species very abundant that reported around $75 \%$ from total shrimp catch (Sumiono, \& Soselisa, 1993). The similar result was also reported during research in deep sea of Pacific and Indian Oceans where Caridea was dominantly catch (Holthuis, 1980; King, 1986):

During:this study some dominant species was also included. The carapace length of deep sea shrimp in west of Sumatera waters ranged from 11.0 to $84.5 \mathrm{~mm}$ (Table 3). This fact indicated that shrimp stock in this area consisted of several cohort. There was no relationship between the water depth of fishing ground with size of deep sea shrimp.

\section{Distribution of Deep Sea Shrimp}

Table 4 presents distribution and occurrence of deep sea shrimp in west Sumatera waters from 50 trawl stations. The high percentage of occurrence of the catch were Aristeus virilis (86\%) followed by Acanthephyra armata $(76 \%)$ and Heterocarpus sp. $(76 \%)$. Distribution of the those species in west of Sumatera waters was very wide. This phenomenon was quite similar with those repoted by Sumiono \& Soselisa (1993) in Kai, Aru, and Tanimbar Islands waters. In contrast the least percentage of occurrence was occupied by group of deep sea scampi such as Nephropsis stewarti and Puerulus angulatus. This fact that might be caused by small number of trawl stations was carried out around coral waters as original fishing ground of these species (Carpenter \& Niem, 1998).

Distribution of deep sea shrimp has a relation with waters depth of fishing ground. Each species occupies and overlaps in certain the depth ranged, they usually like to live in sandy waters while family of Caridea tends to habit in coral waters (King, 1986). In general, the deep sea shrimps distribute in water depth of 200 to 1,000 m except for scampi (Nephropsis stewarti, Puerulus angulatus) which dwelling in depth below $300 \mathrm{~m}$ (Table 4). All of penaeid shrimp (family Penaeidae and Aristeidae) could be found in all range of water depth from 200 to $1000 \mathrm{~m}$.

Table 4 also shows that family Sergestidae did not distribute in all depth range. They were not found in depth of 200 to $500 \mathrm{~m}$. While scampi shrimp family Nephropidae and Palinuridae were only found in this area on the depth of 200 to 500 $\mathrm{m}$. This might be due to their habitat in coral waters whereas in west of Sumatera waters, the depth of this fishing ground was 200 to $500 \mathrm{~m}$. In the western Australian waters it was found the commercial deep sea shrimp that mostly distributed in the depth of 400 to $500 \mathrm{~m}$. This resource had already been exploited commercially by trawl net (Wadley \& Morris, 1991). Sumiono \& Soselisa (1993) pointed out that the distribution of Penaeid shrimp (Aristeidae and Pandalidae) was at the depth of 200 to $1000 \mathrm{~m}$ while scampi shrimp was only caught in the depth of 300 to $500 \mathrm{~m}$. Distribution of scampi was quite similar pattern with result of research done in north and west of Australian waters (Wallner \& Philips, 1988; Davis \& Ward, 1984).

For all species, the highest density of deep sea shrimp resources was recorded in the depth of 750 to $1,000 \mathrm{~m}$ while the smallest density occurred in the depth of 300 to $500 \mathrm{~m}$ as illustrated in Figure 2 . It could be concluded that the best fishing ground of deep sea shrimp resources in west of Sumatera waters was located in the depth of 750 to $1,000 \mathrm{~m}$.

\section{Stock Density and Potential Yield}

Information of stock density, biomass, and potency is needed to arrange development and planning for utilization in fisheries. Table 5 shows

Table 3. Range of carapace length for deep water shrimp in west of Sumatera waters

\begin{tabular}{lc}
\multicolumn{1}{c}{ Jenis (Species) } & Carapace length range $(\mathrm{mm})$ \\
\hline Aristaemorpha foliacea & $26.0-42.0$ \\
Aristeus virilis & $22.0-54.1$ \\
Plesiopenaeus edwardsianus & $25.9-84.5$ \\
Acanthephyra armata & $15.6-27.0$ \\
Heterocarpus sp. & $19.0-45.5$ \\
Heterocarpus ensifer & $16.0-20.5$ \\
Heterocarpus laevigatus & $21.2-65.0$ \\
Plesionika longirostris & $19.7-29.5$ \\
Plesionika martia & $11.0-23.0$ \\
\hline
\end{tabular}


Table 4. Distribution and occurrence (\%) of deep sea shrimp caught in the Sumatera waters of western Indian Ocean

\begin{tabular}{|c|c|c|c|c|}
\hline \multirow{2}{*}{ Species/Family } & \multicolumn{3}{|c|}{ Depth (m) } & \multirow{2}{*}{$\begin{array}{c}\text { Occurrence } \\
(\%)\end{array}$} \\
\hline & $200-500$ & $500-750$ & $750-1,000$ & \\
\hline \multicolumn{5}{|l|}{ Aristeidae } \\
\hline Aristeomorpha foliacea & $x x x x$ & $x x x x$ & $x x x x$ & 10 \\
\hline Aristeu virillis & $x x x x$ & $x x x x$ & $x x x x$ & 86 \\
\hline Plesiopenaeus edwarsianus & $x x x x$ & $x x x x$ & $x x x x$ & 22 \\
\hline \multicolumn{5}{|l|}{ Nephropidae } \\
\hline $\begin{array}{l}\text { Nephropsis stewati } \\
\text { Palinuridae }\end{array}$ & -- & $x x x x$ & -- & 2 \\
\hline Puerulus angulatus & $x x x$ & -- & -- & 4 \\
\hline \multicolumn{5}{|l|}{ Pandalidae } \\
\hline Acanthephyra armata & -- & $x x x x$ & $x x x x$ & 76 \\
\hline Acanthephyra sp. & -- & $x x x x$ & $x x x x$ & 8 \\
\hline Eugonatonotus sp. & -- & $x x x x$ & -- & 2 \\
\hline Heterocarpus dorsalis & -- & -- & $x x x x$ & 2 \\
\hline Heterocarpus ensifer & $x x x x$ & -- & $x x x x$ & 4 \\
\hline Heterocarpus laevigatus & $x x x x$ & $x x x x$ & $x x x x$ & 28 \\
\hline Heterocarpus parvispina & $x x x x$ & $x x x x$ & $x x x x$ & 2 \\
\hline Heterocarpus sp. & $x x x x$ & -- & $x x x x$ & 76 \\
\hline Heterocarpus sp. 1 & $x x x x$ & $x x x x$ & $x x x x$ & 4 \\
\hline Heterocarpus sp.2 & -- & $x x x x$ & $x x x x$ & 32 \\
\hline Heterocarpus sp. 3 & -- & $x x x x$ & $x x x x$ & 22 \\
\hline Parapandalus serratifrons & -- & $x x x x$ & $x x x x$ & 10 \\
\hline Periclimenes sp. & -- & $x x x x$ & $x x x x$ & 4 \\
\hline Plesionika ensis & $x x x x$ & $x x x x$ & $x x x x$ & 54 \\
\hline Plesionika longirostris & $x x x x$ & $x x x$ & $x x x x$ & 10 \\
\hline Plesionika martia & $x x x x$ & $x x x x$ & $x x x x$ & 18 \\
\hline Plesionika sp. & -- & $x x x x$ & -- & 2 \\
\hline Stylodactylus stebbinggi & $x x x x$ & -- & -- & 2 \\
\hline $\begin{array}{l}\text { Stylodactylus sp. } \\
\text { Penaeidae }\end{array}$ & \multicolumn{3}{|c|}{ Penaeidae } & \\
\hline Parapenaeopsis sp. & -- & $x x x x$ & -- & 2 \\
\hline Penaeopsisedwardoi & $x x x x$ & $x x x x$ & -- & 10 \\
\hline \multicolumn{5}{|l|}{ Sergestidae } \\
\hline Acetes sp. & -- & $x x x x$ & $x x x x$ & 66 \\
\hline Acetes sp 1 & -- & $x x x x$ & $x x x x$ & 22 \\
\hline Sergestes sp. & -- & $x x x x$ & $x x x x$ & 42 \\
\hline Sergestes sp. 1 & -- & $x x x x$ & $x x x x$ & 30 \\
\hline \multicolumn{5}{|l|}{ Solenoceridae } \\
\hline Solenocera alfonso & -- & $x x x x$ & $x x x x$ & 34 \\
\hline Solenocera sp. & $x x x x$ & $x x x x$ & $x x x x$ & 24 \\
\hline Solenocera sp. 1 & -- & $X x x x$ & $x x x x$ & 8 \\
\hline
\end{tabular}

stock density of deep sea shrimp in west Sumatera waters from 50 trawl stations.

Table 5 indicates that stock density of deep sea shrimp in west Sumatera waters was fluctuated from 1.6 to $90.38 .5 \mathrm{~kg} \mathrm{~km}^{-2}$ with averaged of 19.8 $\mathrm{kg} \mathrm{km}^{-2}$. The lowest density was obtained in station 17 located in around off Simeulu Island waters, Aceh Province and the highest one was recorded at station 2 in around of Enggano Island waters.
According to spatial stock distribution, it could be stated that south area of west Sumatera waters such as around off Enggano Island (S-1 area) and west off Bengkulu (S-2 area) had higher stock density than north area such as around off Simeulu Island (S-4 area) and west off Aceh waters (S-5 area). In general, stock density in this area was. higher than that of in the southern of Irian Jaya waters with stock density around of $7.9 \mathrm{~kg} \mathrm{~km}^{-2}$ (Suman et al., 1993). 


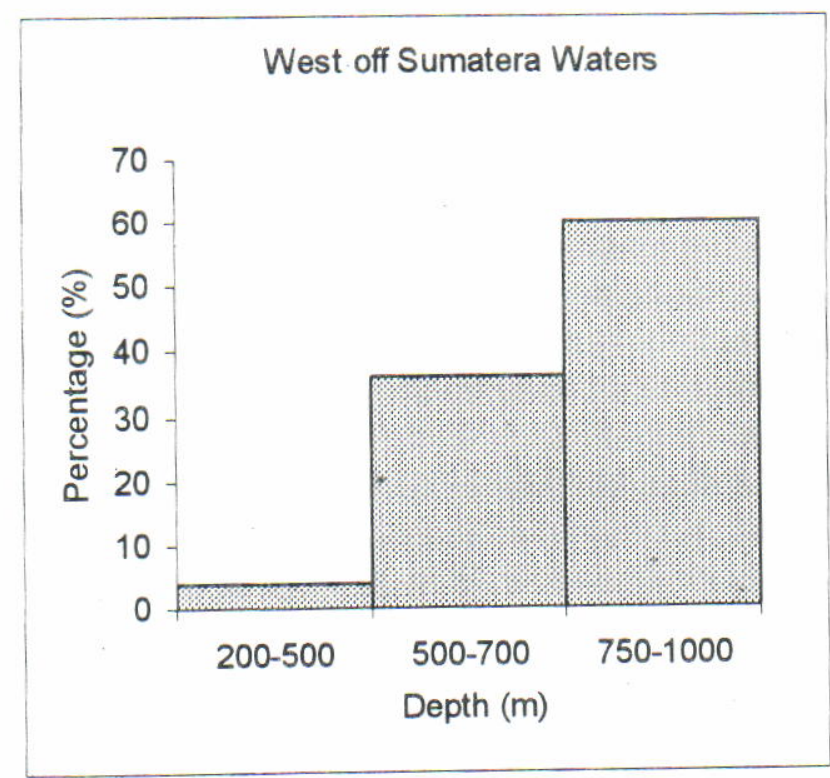

Figure 2. Distribution of deep sea shrimps in the Western Indian Ocean EEZ off Sumatera according to the depth of waters.

Table 5. Stock density of deep sea shrimp $\left(\mathrm{kg} \mathrm{km}^{-2}\right)$ in the Indian Ocean west off Sumatera by area

\begin{tabular}{|c|c|c|}
\hline Area & No.Station & Stock density $\left(\mathrm{kg} / \mathbf{k m}^{2}\right)$ \\
\hline S-1 area & 1 & 26.89 \\
\hline \multirow[t]{8}{*}{ (Around off Enggano Island Waters) } & 2 & 90.38 \\
\hline & 3 & 11.06 \\
\hline & 4 & 20.90 \\
\hline & 5 & 24.20 \\
\hline & 6 & 6.16 \\
\hline & 7 & 8.33 \\
\hline & 8 & 47.25 \\
\hline & 9 & 65.09 \\
\hline S-2 area & 10 & 18.45 \\
\hline \multirow[t]{3}{*}{ (Around off Bengkulu Waters) } & 11 & 10.99 \\
\hline & $\begin{array}{l}12 \\
13\end{array}$ & $\begin{array}{l}13.62 \\
15.15\end{array}$ \\
\hline & 14 & 17.67 \\
\hline S-4 area & 15 & 13.28 \\
\hline \multirow{15}{*}{ (Around off Simeulu Island Waters) } & 16 & 20.09 \\
\hline & 17 & 1.60 \\
\hline & 18 & 46.37 \\
\hline & 19 & 15.35 \\
\hline & 20 & 15.42 \\
\hline & 21 & $\begin{array}{c}41.77 \\
5.58\end{array}$ \\
\hline & $\begin{array}{l}22 \\
23\end{array}$ & $\begin{array}{c}0.00 \\
38.47\end{array}$ \\
\hline & 24 & 14.47 \\
\hline & 25 & 15.29 \\
\hline & 26 & 16.55 \\
\hline & 27 & 10.04 \\
\hline & 28 & 11.58 \\
\hline & 29 & 14.78 \\
\hline & 30 & 13.00 \\
\hline & 31 & 33.87 \\
\hline
\end{tabular}


Countinous

\begin{tabular}{ccc}
\hline Area & No.Station & Stock density $\left(\mathbf{k g} / \mathbf{k m}^{2}\right)$ \\
\hline & 32 & 7.83 \\
& 33 & 15.66 \\
& 34 & 34.32 \\
& 35 & 12.90 \\
& 36 & 28.36 \\
S-5 area & 37 & 23.15 \\
(Around off Aceh Waters) & 38 & 24.82 \\
& 39 & 16.78 \\
& 40 & 16.34 \\
& 41 & 3.47 \\
& 42 & 14.23 \\
& 43 & 11.54 \\
& 44 & 0 \\
& 45 & 20.94 \\
& 46 & 4.59 \\
& 47 & 1.70 \\
& 48 & 30.81 \\
& 49 & 29.55 \\
& 50 & 18.79 \\
\hline
\end{tabular}

Based on 50 research stations, average of stock density was $20.34 \mathrm{~kg} \mathrm{~km}^{-2}$ in the total area estimated $7,124.32 \mathrm{~km}^{2}$. It could be predicted that total biomass of deep sea shrimp in west off Sumatera waters was 145 ton. Because of no fishing effort exploited this resources in this area, potency of deep sea shrimp stock in west Sumatera waters would be a half of total biomass (Gulland, 1983), so the potency of deep sea shrimp in this area was estimated 73 ton. Identification in each area shows that the highest potency was recorded in S-1 area (around off Enggano Island), it could be stated that in this area might be the most suitable area for development of the deep sea shrimp exploitation in west off Sumatera waters.

\section{CONCLUSSION}

1. The deep sea shrimps caught in EEZI area of west Sumatera waters consisted of 33 species that were dominated by Heterocarpus $\mathrm{sp}$. recorded $30.75 \%$. Most of them categorized as commercially species.

2. The deep sea shrimp could be found in the depth of 200 to $1000 \mathrm{~m}$ with the highest density found in the depth of 500 to $750 \mathrm{~m}$, and the widest area distribution was stout red shrimp (Aristeus virilis) about $86 \%$.

3. Area S-1 around off Enggano Islands waters and area S-2 west off Bengkulu waters had higher stock density compared with those of around area S-4 off Simeulue waters and area S-5 west off Aceh waters.

4. Potential yield of deep sea shrimp in west Sumatera of Indian Ocean EEZI waters was estimated about 73 ton per year and the most suitable area for exploitation of deep sea shrimp found in S-1 area (around off Enggano Island waters).

\section{REFERENCES}

Anonymous. 1972. Survey Samudera Indonesia (tanggal 12 Nopember sampai dengan 1 Desember, 1972). Laporan Penelitian Perikanan Laut. No.1. 27-58.

Anonymous. 2005. The Japan-Indonesia deep sea fishery resources joint exploration project (Report of 2004 Field Survey. OFCF-RIMF. 54 p.

Carpenter, K. E. \& V. H. Niem (Eds). 1998. FAO Identification guide for fishing purpose. The living marine resources of the Western Central Pasific. Vol. 2. Cephalopods, Crustaceans, Holothinians, and Sharks. Rome.

Davis, T. L. O. \& T. S. Ward. 1984. CSIRO finds two new scampi ground $s$ off the north west shelf. Austr. Fish. Vol.43 (8): 41-45. 
George, M. J. 1967. On a collection of Penaeid prawns from the offshore water of the southwest India. In Proceeding of symposium on crustacea. Part 1. p 337-344.

Gulland, J. A. 1983. Fish stock assessment. A Manual of Basic Methods. John Wiley \& Sons. Chicester. 233 p.

Holthuis, L. B. 1980. FAO species catalogue. Vol.1. Shrimps and prawns of the world. An annotated catalogue of species interest to fisheries. FAO Fish. Synop. (125) Vol.1: 261 p.

Holthuis, L. B. 1991. FAO species catalogue. Vol.13. Marine lobsters of the world. An annotated and illustrated catalogue of species interest to fisheries know to date. FAO Fish. Synop. (125) Vol.13: 292 p.

King, M. J. 1986. Deep water shrimps. The fishery resources of Pacific Island countries. Part I FAO Fish. Tech. Pap. (272.1): 45 p.

RCCF. 2003. Sumber daya udang laut di Indonesia: Potensi dan tingkat pemanfaatannya. Pusat Riset Perikanan Tangkap. Badan Riset Kelautan dan Perikanan. 15 hal.

Saeger, J., P. Martosubroto, \& D. Pauly. 1976. Fish report of the Indonesia German demersal fisheries project. Result of a trawl survey in the. Sunda Shelf area. Laporan Penelitian Perikanan Laut. No.1: 1-46.

Shindo, S. 1973. General review of the trawl fisheries and the demersal fish stock of the South China Sea. FAO Fish. Tech. Pap. No.120. FAO. Rome.
Sparre, P. \& S. C. Venema. 1992. Introduction to tropical fish stock assesment. Part I. Manual. FAO Fish. Tech. Pap. No.306/1

Suman, A., A. A. P. Widodo, \& S. Budihardjo. 1993. Stok sumber daya udang di perairan ZEE Selatan Irian Jaya. Jurnal Penelitian Perikanan Laut. No.71: 101-108.

Sumiono, B. \& Iskandar B. 1993. Distribution and stock density of deepwater prawns in the waters of Tanimbar and Timor sea. Jurnal Penelitian Perikanan Laut. No.77: 1-15.

Sumiono, B. \& J. Soselisa. 1993. Udang laut dalam di perairan Kai dan Tanimbar (bagian 1: Jenisjenis udang dan penyebarannya. Jurnal Penelitian Perikanan Laut. No.73: 45-56.

Naamin, N. 1984. Dinamika populasi udang jerbung (Penaeus merguiensis de Man) di perairan Arafura dan alternatif pengelolaannya. Disertasi Doktor pada Fakultas Pasca Sarjana. Institut Pertanian Bogor. Bogor. 381 hal.

Naamin, N. 1987. Perikanań laut di Indonesia: Prospek dan problema pengembangan sumber daya perikanan laut. Makalah disampaikan pada Seminar Laut Nasional II. Jakarta. 26 hal.

Wadley, V. A. \& S. L. Morris. 1991. Deep water fishery for prawn and carids off Western Australia. In Davie, P. J. S. \& R. H. Quinn (Eds): Memoirs of the Queensland Museum. Published by order of the board Vol.31: 466.

Wallner, B. \& B. Phillips. 1988. From scampi to deep water prawn: Developments in the north west shelf deep water trawl fishery. Australian Fisheries. Vol.47. No.9: 34-38. 

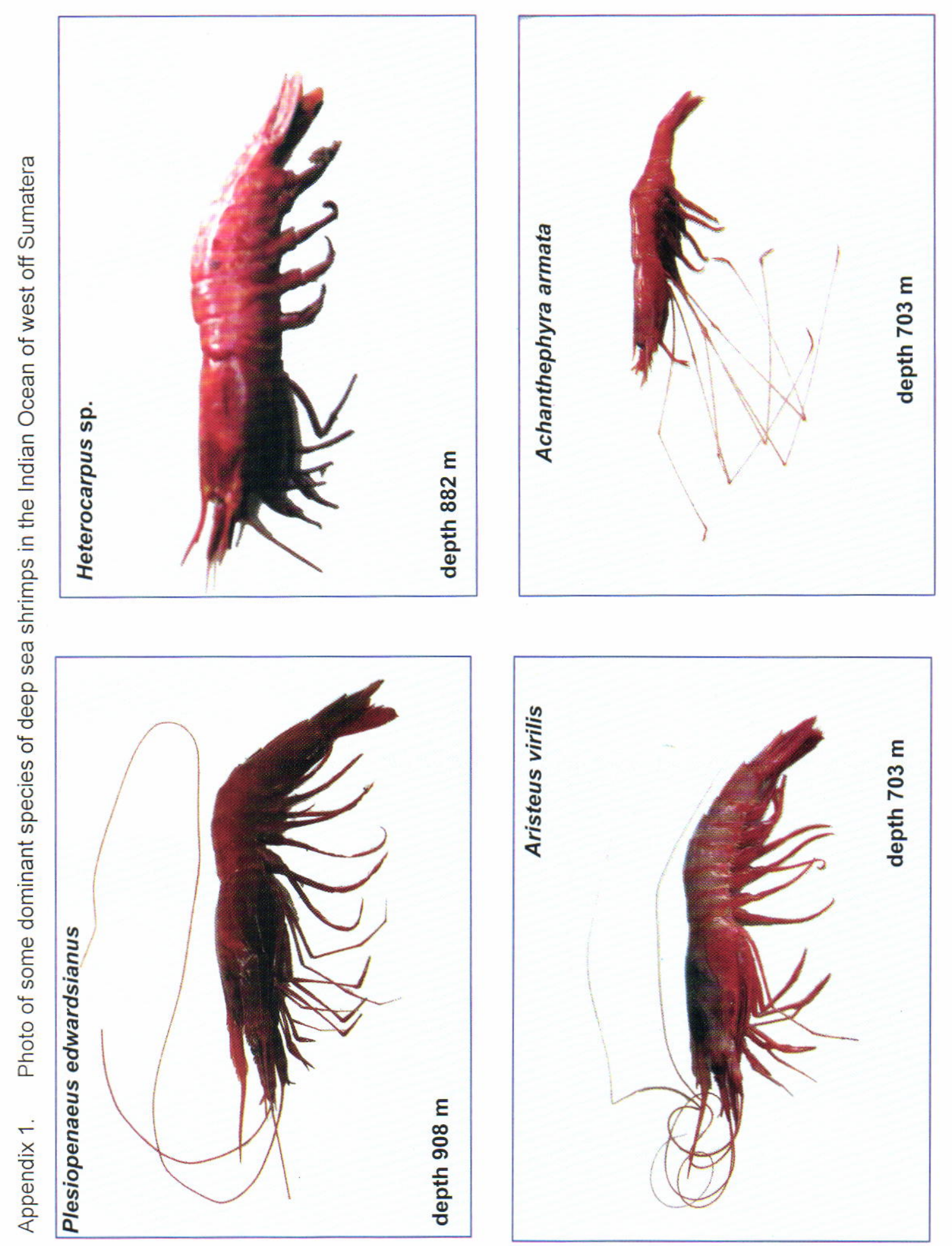
